\title{
Performance of Lactating Murrah Buffaloes Supplemented with Fenugreek (Methi) Seed
}

\author{
M. Kirar ${ }^{1}$, S. Ghosh ${ }^{2}$, R.P.S. Baghel ${ }^{1}$, A. Jain ${ }^{1}$, G.P. Lakhani ${ }^{1}$, B. Roy ${ }^{1}$ and A.K. Jain ${ }^{1}$ \\ ${ }^{1}$ College of Veterinary Science and Animal Husbandry, Jabalpur, India \\ ${ }^{2}$ Nanaji Deshmukh Veterinary Science University, -482001, Madhya Pradesh, India \\ *Corresponding author
}

\section{A B S T R A C T}

The study was conducted on twelve lactating Murrah buffaloes which were randomly distributed into 2 groups consisting of six animals in each group i.e. control group without

\section{Keywords}

Murrah buffaloes,

Fenugreek, Milk production, Milk composition, Blood biochemical

Article Info

Accepted: 04 June 2018 Available Online: 10 July 2018 any fenugreek supplementation and treatment group supplemented with soaked fenugreek seeds@100 g per animal per day. The animals were maintained under same managemental conditions. The observations were recorded 3 months ( 90 days) postpartum. Parameters observed during the study period were milk production, milk composition (fat, protein, lactose, total solid and solid not fat) and blood biochemical parameters (blood glucose, serum calcium, serum cholesterol, serum total protein, serum globulin and serum albumin). The fenugreek supplemented group had higher daily milk yield and 3 months total milk yield (litres) compared to control group, but there was no significant difference between the two groups. The average was higher in treatment group than the control group, but the difference was not significant. There was no significant difference in milk components like fat, protein, lactose, SNF and Total Solid in lactating Murrah buffaloes. There was also no significant difference in average serum calcium, serum cholesterol, serum total protein, serum albumin and serum globulin concentrations between the groups. The blood glucose concentration was significantly $(\mathrm{P}<0.05)$ lower in the fenugreek supplemented group compared to the control group.

\section{Introduction}

Fenugreek (Trigonella foenum-graecum L. Leguminosae) is derived from a plant that belongs to the leguminous family. It is commonly known as methi and is found in India, Middle East, North Africa and South Europe. It has a high proportion of protein (approximately 20\%-30\%), the fatty acids ranged from $5-10 \%$ which are predominantly linoleic, linolenic, oleic and palmitic acids. It had $45-65 \%$ total carbohydrates with $15 \%$ of galactomannan (a soluble fiber). Also, it contains flavonoids, saponins and more calcium, phosphorous, iron, zinc and manganese (Schryver, 2002). It contains amino acid (4 hydroxyisoleucine) which has been shown to stimulate insulin secretion and improve glucose tolerance in normal and diabetic animals as the result of direct $B$ - cell 
stimulation (Broca et al., 1999; Sauvaire et al., 1998; Schryver, 2002). Fenugreek seeds are used for the treatment of diabetes mellitus in many parts of the world including India (Kumar et al., 2015). Saponins components are considered as an appetizer and helps digestion. Fenugreek contains phytoestrogens (Mazur et al., 1998), and it has been recognized as a potential source of diosgenin, a basic compound in the hemisynthesis of steroidal sapogenins such as cortisol and sex hormones (Brenac and Sauvaire 1996 a, b). The seeds are highly valued as food for man, cattle and sheep and to promote lactation and lactation performance in woman and ruminant (Trian, 2003).

Fenugreek has been shown to have a positive effect on lactation performance in ruminants such as dairy cows, buffaloes and dairy goats (Nasser et al., 2013; EL- Basheir 2015; Degirmencioglu et al., 2016). The seeds of fenugreek are known to have hypoglycaemic, hypocholesterolemic, gastro and hepatoprotective, and anti-oxidant properties. Fenugreek seeds also lowered serum triglycerides, total cholesterol and low-density lipoprotein cholesterol. These effects may be due to sapogenins (substance in fenugreek) which increase biliary cholesterol extraction in turn leading to lower serum cholesterol level (Sauvaire et al., 1991).

As regards, the use of fenugreek in buffalo in Indian condition is not well documented by the researcher or there is paucity of literature. Therefore, the research work was undertaken to investigate the effect of fenugreek supplementation on buffaloes that are adapted to the Indian environment. Considering the above facts, the present study was designed to evaluate the influence of fenugreek on the production performance and blood biochemical parameters of lactating Murrah buffaloes under Indian conditions.

\section{Materials and Methods}

The study was conducted at Livestock Farm, Adhartal, College of Veterinary Science and A.H., Nanaji Deshmukh Veterinary Science University, Jabalpur, Madhya Pradesh, India. Twelve lactating Murrah buffaloes of 1 st to 3rd parity were randomly selected and distributed into two different groups with six animals in each group. The experimental animals were fed according to their body weight and production (ICAR, 2013).

\section{Fenugreek supplementation}

Animals in Group I were control without any supplementation and in Group II were supplemented with soaked fenugreek seeds@ $100 \mathrm{~g}$ per animal per day.

\section{Data recorded}

The milk yield was recorded individually daily throughout the experimental period and then milk yield was calculated up to three months of lactation.

The milk components including fat, protein, lactose, total solids and Solid Not Fat (SNF) were analyzed from calving to 12 weeks postpartum at weekly interval for all the animals. The representative milk samples of individual animals were collected from the milking bucket in plastic sample bottles after completion of complete milking of the individual animal. The milk samples were analysed by auto analyzer (Ultrasonic auto milk analyzer, Netco Pvt. Ltd.).

\section{Blood biochemical analyses}

Blood samples (6-8 $\mathrm{ml}$ each) were collected aseptically in a vial containing anticoagulant by jugular vein-puncture from the animals in each group at fortnightly interval. Blood samples were also collected without 
anticoagulant for separation of serum. One $\mathrm{ml}$ of blood sample was treated with sodium fluoride $(5 \mathrm{mg} / \mathrm{ml})$ for glucose estimation.

The blood samples were kept in ice bucket and transported quickly to the laboratory for further processing. In the laboratory, collected blood samples were centrifuged for further analysis. Plasma and serum were analysed for calcium, glucose, cholesterol, total protein, albumin and globulin by blood biochemical analyser using appropriate commercial kit.

\section{Statistical analysis}

Data were analyzed, using ANOVA described by Snedcor and Cochran (1994) to study the impact of fenugreek feeding on performance of lactating Murrah buffaloes.

\section{Results and Discussion}

The average daily milk yield (litres) was higher in fenugreek supplemented group compared to the control group during the experimental period (Table 1). The average total milk yield (litres) of lactating Murrah buffaloes in first 3 months was higher in the fenugreek supplemented group than control group (Table 1), but the difference was not significant. The higher milk yield in fenugreek supplemented group compared to control group, although not significant, may be due to the effect of diosgenin, which is a chemical compound in fenugreek seeds similar to the hormone oestrogen stimulating an increase in milk flow (Trian 2003). Similarly, Tomar et al., (1996) reported that feeding of linseed oil @ $200 \mathrm{ml}$ and methi seeds @ $200 \mathrm{~g}$ in Murrah buffaloes even at every fourth day lead to an increase in milk yield. Abo El-Nor et al., (2007) reported that supplementation of $200 \mathrm{~g}$ fenugreek seeds resulted in significant $(\mathrm{p}<0.05)$ increase in milk yield in lactating buffaloes. Maher and Nadya (2012) reported that feeding of 2 or $4 \%$ of fenugreek seeds in
Friesian cows and Nasser et al., (2013) reported that supplementation of $50 \mathrm{~g}$ and 100 $\mathrm{g}$ of fenugreek seed powder per cow per day in Sharabi cows significantly $(\mathrm{p}<0.05)$ increased milk yield. Degirmencioglu et al., (2016) also reported that supplementation of $50 \mathrm{~g}$ ground fenugreek seeds significantly $(p<0.01)$ increased mean daily milk production in Anatolian water buffaloes. Other workers, like Alamer and Basiouni (2005), Ahmed and Al-Janabi (2012), Balgees et al., (2013), Jordaan (2014) and EL-Basheir (2015) reported that fenugreek supplementation significantly $\quad(p<0.05) \quad$ increased milk production in various breeds of goats. Further, Samia et al., (2012) and Al-Sherwany (2015) also reported fenugreek supplementation significantly $\quad(\mathrm{p}<0.05) \quad$ increased milk production in various breeds of sheep.

In the present study, there was no significant effect of $100 \mathrm{~g}$ supplementation of fenugreek seeds on fat, protein, lactose, solid not fat and total solids in the milk of Murrah buffaloes (Table 1). Similar to these findings, Shah and Mir (2004) reported that effect of feeding fenugreek seed at $20 \%$ of diet dry matter resulted in no significant difference in milk composition between the treatment and control groups. The result of this study is also in agreement with El- Alamy et al., (2001) who found that feeding fenugreek seeds to buffaloes had no effects on milk composition. Kholif and Abdel-Gawad (2001) also reported that there was no significant difference on milk lactose content in fenugreek supplemented group compared to control group. Balgees et al., (2013) similarly reported that milk components (protein, lactose and SNF) showed inconsistent pattern by fenugreek seeds supplementation but there was significant $(\mathrm{p}<0.05)$ decrease in milk fat percentage. EL- Basheir (2015) also reported that supplementation of fenugreek seeds @0, 2.5 and $5 \%$ of the diet did not affect milk composition. Degirmencioglu et al., (2016) 
also reported that supplementation of $50 \mathrm{~g}$ of ground fenugreek seeds in Anatolian water buffaloes had no significant effect on SNF and protein percentages in milk. In contrast to the findings of the present study, Ahmed and AlJanabi (2012) reported that supplementation of $4 \%$ and $6 \%$ fenugreek seed powder in lactating Damascus crossbred goats resulted in significant decrease $(p<0.05)$ in milk fat percentage in the treated groups compared to control group. Nasser et al., (2013) reported that supplemented fenugreek seed powder at a level 50 or $100 \mathrm{~g} / \mathrm{cow} /$ day in Sharabi dairy cows resulted in significantly $(\mathrm{p} \leq 0.05)$ increased milk fat percentage. Al-Sherwany (2015) reported that supplementation of fenugreek seeds to the basal ration at level of 0.6 and $1.2 \mathrm{~g} / \mathrm{kg}$ live body weight in Hamdani ewes resulted in significant $(\mathrm{p}<0.05)$ increase in milk protein and solid not fat percentage, while percentage of milk fat and milk lactose decreased significantly.
In the present study, $100 \mathrm{~g}$ fenugreek seeds supplementation resulted in significant $(p<0.05)$ decrease in blood glucose concentration but, there was no significant effect on concentration of serum calcium, serum cholesterol, serum total protein, serum albumin and serum globulin (Table 2).

The findings of the present study with respect to blood glucose is in agreement with the findings of Alamer and Basiouni (2005) who reported that supplementation of $60 \mathrm{~g}$ per day fenugreek seeds in goats exhibited significantly lower plasma levels of glucose $(\mathrm{p}<0.05)$ compared to control group. Similarly, Ahmed and Al-Janabi (2012) reported that supplementation of $4 \%$ and $6 \%$ fenugreek seeds powder in lactating Damascus crossbred goats resulted in significant $(\mathrm{p}<0.05)$ lowered blood glucose but increased serum total protein level as compared to control group.

Table.1 Effect of fenugreek on milk traits (Mean \pm SE) in lactating Murrah buffaloes

\begin{tabular}{|l|c|c|}
\hline \multicolumn{1}{|c|}{ Parameters } & Control diet & Test diet \\
\hline Average daily milk yield (litres) & $5.40 \pm 0.13$ & $7.58 \pm 0.11$ \\
\hline 3 months total milk yeild (litres) & $2706.60 \pm 24.45$ & $3805.01 \pm 21.58$ \\
\hline Milk Fat (\%) & $6.47 \pm 0.11$ & $6.58 \pm 0.11$ \\
\hline Milk Solid Not Fat (\%) & $9.63 \pm 0.10$ & $9.66 \pm 0.10$ \\
\hline Milk Protein (\%) & $3.57 \pm 0.05$ & $3.53 \pm 0.04$ \\
\hline Milk Lactose (\%) & $4.95 \pm 0.08$ & $5.13 \pm 0.06$ \\
\hline Milk Total solid (\%) $(\%)$ & $15.59 \pm 0.18$ & $16.12 \pm 0.42$ \\
\hline
\end{tabular}

Table.2 Effect of fenugreek on blood biochemical parameters (Mean \pm SE) in lactating Murrah buffaloes

\begin{tabular}{|l|c|c|}
\hline \multicolumn{1}{|c|}{ Parameters } & Control diet & Test diet \\
\hline Serum Calcium $(\mathbf{m g} / \mathbf{d l})$ & $10.29 \pm 0.36$ & $9.80 \pm 0.38$ \\
\hline Serum Cholesterol $(\mathbf{m g} / \mathbf{d l})$ & $44.96 \pm 4.28$ & $41.43 \pm 3.92$ \\
\hline Serum Total Protein $(\mathbf{g} / \mathbf{d l})$ & $6.67 \pm 0.19$ & $6.71 \pm 0.12$ \\
\hline Serum Albumin $(\mathbf{g} / \mathbf{d l})$ & $3.19 \pm 0.16$ & $3.64 \pm 0.18$ \\
\hline Serum Globulin $(\mathbf{g} / \mathbf{d l})$ & $3.47 \pm 0.25$ & $3.07 \pm 0.19$ \\
\hline Blood Glucose $(\mathbf{m g} / \mathbf{d l})$ & $68.72^{\mathrm{a}} \pm 1.25$ & $61.06^{\mathrm{b}} \pm 1.72$ \\
\hline
\end{tabular}

${ }^{a, b}$ Means within a row with different superscripts differ significantly $(\mathrm{P}<0.05)$. $\mathrm{g}=\mathrm{Gram}, \mathrm{dl}=$ Decilitre 
Babekir (2015) also reported that increasing fenugreek level to $15 \%$ in Nubian goats lead to a decrease in blood glucose level but was not statistically significant $(\mathrm{p}<0.05)$. They also reported that fenugreek seeds supplementation at the rate of 5\%,10\% and $15 \%$ resulted in significant $(\mathrm{p}<0.05)$ decrease in serum cholesterol and total protein concentration compared to control.

Al-Sherwany (2015) also reported that addition of fenugreek seeds to basal ration at the level 0.6 and $1.2 \mathrm{~g} / \mathrm{kg}$ live body weight in Hamdani ewes resulted in no significant change in cholesterol and globulin concentrations compared to the control group.

The decrease in blood glucose concentration in the fenugreek supplemented groups may be due to the fact that fenugreek seeds contain $50 \%$ pectin that forms a colloid suspension when hydrated which decreases the rate of gastric emptying and inhibition of glucose transporter leading to slow carbohydrate absorption (Al-Habori and Raman 1998). However, Bordia et al., (1997) reported that fenugreek seeds contain chemicals that slow down the time that food takes to go through the intestinal tract leading to slow absorption of sugars and blood sugar levels may not rise as high or fluctuate as much as usual. The low blood glucose concentration due to fenugeek supplementation may also be due to the presence of an amino acid called 4 hydroxy iso leucine in fenugreek seeds which appears to act on pancreatic beta cells to increase the body's production of insulin. Higher amounts of insulin production may decrease the sugar that stays in the blood (Broca et al., 2000; Schryver 2002). The findings of Raju et al., (2001) and Devi et al., (2003) that the ability of fenugreek seeds to modulate key glucose metabolizing enzymes such as hexokinase (glycolysis), glucose-6-phosphatase or fructose-1,6- bisphosphatase (gluconeogenesis) also might be considered as a possible mechanism. The present findings are in contrast with the findings of Shah and Mir (2004), who reported that the supplementation of fenugreek seed at $20 \%$ of diet dry matter resulted in reduction in blood cholesterol concentration (by $4 \%$ units more than the control diet) in a 3 -week study without altering milk flavour or taste. Similarly, Abo El-Nor et al., (2007) reported that supplementation of $200 \mathrm{~g}$ fenugreek seeds resulted in significant $(\mathrm{p}<0.05)$ increase in blood glucose, total protein and albumin but non-significant lower values of cholesterol. Abbas et al., (2012) reported that supplementation of dietary fenugreek seeds at the rate of $3 \%$ of body weight had insignificant elevation of serum total protein and blood glucose concentrations but cholesterol concentration had a significant $(\mathrm{p}<0.01)$ reduction as compared with control. Ishtiyak et al., (2013) reported that supplementation of raw fenugreek seeds at $3 \%$ of dry matter intake resulted in significant $(\mathrm{p}<0.05)$ increase in total serum protein and serum albumin but there was no significant difference in serum globulin and serum cholesterol levels.

In conclusion, the results of the present study showed that supplementation of fenugreek seeds on lactating Murrah buffaloes resulted in a increase in milk production although nonsignificant, no change in milk composition and significantly decrease in blood glucose concentration. Fenugreek can be used as feed supplementation but further study is required with more number of animals and for longer duration.

\section{References}

Abbas, S, F., Abd El-Ati, M, N., Allam, F. M. and Daghash, M. W. H. 2012. Effect of dietary fenugreek seeds on growth and carcass characteristics of Saidi lambs. Egyptian Journal of Nutrition 
and Feeds. 15(1): 91-101.

Abo El-Nor, S. A. H., Khattab, H. M., AlAlamy, H. A., Salem, F. A. and Abdou, M. M. 2007. Effect of some medicinal plants seeds in the rations on the productive performance of lactating buffaloes. International Journal of Dairy Science 2: 348-55.

Ahmed, A. K. and Al-Janabi, F. 2012. Feeding effects of Fenugreek seeds (Trigonella foenum graecum L.) on lactation performance, some serum constituents and prolactin hormone level in Damascus crossbred goats. Diyala Agricultural Sciences Journal. 4(1): $1-8$.

Al-Habori, M, and Raman, A. 1998. Antidiabetic and hypocholesterolaelmic effect of fenugreek. Phytotherapy Research. 12: 233-242.

Al -Sherwany, D. A. O. 2015. Feeding effects of fenugreek seeds on intake, milk yield, chemical composition of milk and some biochemical parameters in Hamdani ewes. Journal Veterinary Science. 8(1): 49-54.

Alamer, M. A. and Basiouni, G. F. 2005. Feeding effects of Fenugreek seeds (Trigonella foenum graecum L.) on lactation performance, some plasma constituents and growth hormone level in goats. Pakistan Journal of Biological Sciences. 8(11): 1553-56.

Babekir, N. S. 2015. Effect of Fenugreek (Trigonella foenum graecum) seed supplementation on feed intake and chemical blood profile of Nubian Goats. M.Sc. (Animal Production) Thesis, University of Khartoum.

Balgees, A. A. E., Jame, N. M., Rahmatalla, S. A., Amasiab, E. O. and Mahala, A. G. 2013. Effect of Fenugreek Seeds Supplementation on feed intake, some metabolic hormone profile, milk yield and composition in Nubian Goats.
Research Journal of Animal Sciences. 7 (1): 1-5.

Bordia, A., Verma, S. K. and Srivastava, K. C. 1997. Effect of ginger (Zingiber officinale Rosc.) and fenugreek (Trigonella foenumgraecum L.) on blood lipids, blood sugar and platelet aggregation in patients with coronary artery disease. Prostaglandins, Leukotrienes and Essential Fatty Acids. 56: 379-384.

Brenac, P. and Sauvaire, Y. (1996a).Chemotaxonomic value of sterols and steroidal sapogenins in the genus Trigonella. Biochemical Systematics and Ecology. 24: 157-164

Brenac, P. and Sauvaire, Y. (1996b). Accumulation of sterols and steroidal sapogenins in developing fenugreek pods: possible biosynthesis in situ. Phytochemistry. 41: 415-422.

Broca, C., Gross, R., Petit, P., Sauvaire, Y., Manteghetti, M., Tournier, M., Masiello, P., Gomis, R. and Ribes, G. 1999. 4-Hydroxyisoleucine: experimental evidence of its insulinotropic and antidiabetic properties. American Journal of Physiology. 277: 617-623.

Broca, C., Manteghetti, M., Gross, R., Baissac, Y., Jacob, M., Petit, P., Sauvaire, Y. and Ribes, G. 2000. 4Hydroxyisoleucine: effects of synthetic and natural analogues on insulin secretion. European Journal of Pharmacology. 390: 339-45.

Degirmencioglu, T., Unal, H., Ozbilgin, S. and Kuraloglu, H. 2016. Effect of ground fenugreek seeds (Trigonella foenum-graecum) on feed consumption and milk performance in Anatolian water buffaloes. Archives Animal Breeding. 59: 345-349.

Devi, B. A., Kamalakkannan, N. and Prince, P. S. 2003. Supplementation of fenugreek leaves to diabetic rats- 
Effect on carbohydrate metabolic enzymes in diabetic liver and kidney. Phytotherapy Research. 17(10): 12311233.

El-Alamy, H. A., Khattab, H. M., El-Nor, S. A., Salam, F. A. F. and Abdou, M. M. 2001. Milk production response to supplementing rations with some medical herbs of lactating buffaloes. Proceedings of the Eighth Egyptian Conference for Dairy Science and Technology, Research papers II, pp. 675-686.

EL-Basheir, A. A. 2015. The addition of Fenugreek seeds to ration on milk yield, composition and kids growth rates of Sudanese Nubian goats. M.Sc. (Animal Production) Thesis, University of Khartoum.

Indian Council of Agricultural Research. 2013. Nutrient Requirements of Cattle and Buffalo. $3^{\text {rd }}$ Edn., New Delhi.

Ishtiyak, A. M., Kumar, R., Ahmad, T. and Fayaz, A. S. 2013. Effect of dietary supplementation of raw fenugreek seeds (Trigonella foenum-graecum) on blood biochemical profile in goats. Indian Journal of Animal Nutrition. 30(3): 242-45.

Jordaan, H. P. 2014. The effect of a natural feed additive, fenugreek, on feed digestibility and milk response in dairy goats. M.Sc. (Agriculture) Thesis, Stellenbosch University.

Kumar, K., Kumar, S., Datta, A. and Bandyopadhyay, A. 2015. Effect of fenugreek seeds on glycemia and dyslipidemia in patients with type 2 diabetes mellitus. International Journal of Medical Science and Public Health. 4 (7): 997-1000.

Maher, A. H. and Nadya, M. B. 2012. Effect of using Fenugreek seeds on milk yield and composition of local Friesian Cows. Journal of Tikrit University for Agriculture Sciences.
12(4): 41-46.

Mazur, W. M., Duke, J. A., Wahala, K., Rasku, S. and Adlercreutz, H. 1998. Isoflavonoids and lignins in legumes: Nutritional and health aspects in human. Journal of Nutritional Biochemistry. 9: 193-200.

Nasser, A. K., Shams Al-dain, Q. Z. and Abou, N. Y. 2013. Using fenugreek seeds powder as a feed additive in rations of Sharabi local cows and its effect on milk production and chemical composition. Iraqi Journal of Veterinary Sciences. 27(1): 13-19.

Raju, J., Gupta, D., Rao, A. R., Yadava, P. K. and Baquer, N. Z. 2001. TSP foenum graecum (fenugreek) seed powder improves glucose homeostasis in alloxan diabetic rat tissues by reversing the altered glycolytic, gluconeogenic and lipogenic enzymes. Molecular and Cellular Biochemistry. 224: 45-51.

Samia, A. A. H., Sania, A. I. S., Salih, K., Muddither, A., Kheder, S. I. and Barsham, M. A. 2012. Effect of oral administration of Trigonella foenum L. (seeds) on galactagogue, body weight and hormonal levels in Sudanese desert sheep. Journal of Pharmaceutical and Biomedical Sciences. 22(24): 1-5.

Sauvaire, Y., Ribes, G. and Baccou, J. C. 1991. Implication of steroid saponins and sapogenins in the hypocholesterolemic effect of fenugreek. Lipids. 26: 191-197.

Sauvaire, Y, Petit, P., Broca, C., Manteghetti, M., Baissac, Y., Fernandez-Alvarez, J., Gross, R., Roye, M., Leconte, A., Gomis, R. and Ribes, G. 1998. 4Hydroxyisoleucine: a novel amino acid potentiator of insulin secretion. Diabetes. 47: 206-210.

Schryver, T. 2002. Fenugreek. Total Health. 24: $42-44$ 
Shah, M. A. and Mir, P. S. 2004. Effect of dietary fenugreek seed on dairy cow performance and milk characteristics. Canadian Journal of Animal Science. 84: 725-29.

Snedecor, G. W. and Cochran, W. G. 1994. Statistical Methods. 7th Edn., Oxford and IBH Publishing Co., New Delhi.

Tomar, K. S., Singh, V. P. and Yadav, R. S. 1996. Effect of feeding maithy
(Trigonella foenum-graecum) and Chandrasoor (Lepidium sativum $\mathrm{L}$ ) seeds on milk and blood constituents of Murrah buffaloes. Indian Journal of Animal Sciences. 66:1192-93.

Trian, D. 2003. The use of Fenugreek for breast feeding women. Complementary Therapies in Nursing and Midwifery. 9: 155-56.

\section{How to cite this article:}

Kirar, M., S. Ghosh, R.P.S. Baghel, A. Jain, G.P. Lakhani, B. Roy and Jain, A.K. 2018. Performance of Lactating Murrah Buffaloes Supplemented with Fenugreek (Methi) Seed. Int.J.Curr.Microbiol.App.Sci. 7(07): 70-77. doi: https://doi.org/10.20546/ijcmas.2018.707.009 